Helena Sagar is a part-time PhD student at an interdisciplinary research school, at the University of Gothenburg, Sweden. Helena's research interest takes its points of departure in her work as a science and technology teacher in compulsory school. Helena has a back-ground in genetic engineering at Genencor International Inc in California, USA, where she was part of the enzymology team investigating the effect of random mutagenesis on a specific protease's activity in laundry detergents. Helena's experience as a "real-life scientist" has had an influence on her view of knowledge and her efforts to create authentic learning environments for her own students.

Ann-Marie Pendrill is professor of physics at University of Gothenburg, with a research background in computational atomic physics. During recent years her interests have shifted to various aspects of education. Since 2009 , she is also the director of the Swedish National Resource Centre for Physics Education, located at Lund University.

Anita Wallin is a senior lecturer in science education at the Department of Pedagogical, Curricular and Professional Studies, University of Gothenburg, Sweden. Anita's research interest emphases learning and teaching science, primarily biology. The key focus of her research is to identify critical aspects for learning of specific content in classrooms. The findings of this research become "content oriented theories". Anita is director of PhD-studies at the department and supervises four PhDstudents. She is teaching in both pre- and in-service teacher education.

HELENA SAGAR

Kullaviksskolan, Kullavik, Sweden.

Department of Physics, University of Gothenburg, Sweden

helena.sagar@kungsbacka.se

ANN-MARIE PENDRILL

Department of Physics, University of Gothenburg, Sweden

ANITA WALLIN

Department of Education, University of Gothenburg, Sweden

\title{
Teachers' Perceived Requirements for Collaborating with the Surrounding World
}

\begin{abstract}
This study identifies teachers' perceptions of requirements for including collaborations with the surrounding world in their teaching practice, with the aim of providing authentic and entrepreneurial learning environments for students. School management, time and teachers' personal character traits and disposition were the most frequently stated areas of concern, followed by colleagues, surrounding world, economy and professional development. Concerns not previously identified include economy, localities, local curriculum, teachers' unions as well as time to reflect and adjust to a different teaching approach. The results are worth considering for school and teacher development aimed at increasing school collaboration with the surrounding world.
\end{abstract}

\section{INTRODUCTION}

Collaboration between School and the Surrounding world, CSS, is encouraged by curricular reforms in Sweden and elsewhere for the purpose of shaping more authentic and entrepreneurial learning environments for the students. This paper focuses on the teacher's role in relation to inclusion of CSS as an integrated part of teaching. The collaboration aspects involved in an authentic and entrepreneurial teaching practice constitute the point of departure. 
The main purpose of CSS is to present the school subjects in their real-life contexts, for the students to get insight into the usefulness of the content, concepts and skills taught in school and how these are used outside school in authentic settings. This may help the students to change some stereotyped images which they might hold of certain professions, especially in the fields of science and technology (Aikenhead, 2004; Schreiner, 2006). Furthermore, CSS creates possibilities for students to present school work outside school, which has been found to increase student motivation for school work and learning (McCombs, 1996; NRC, 2000). Additionally, for CSS to be a truly integrated part of teaching the collaborations have to help the students reach the national and individual goals; the surrounding world is one among many resources for the students' formal learning. Finally, the surrounding world can be represented by a variety of actors, who can work in collaboration with the school. The collaboration can take place outside or inside the school building. CSS is here defined as:

- The students visiting or making contact, individually or in group and for a learning purpose, with the surrounding world by telephone, letter, e-mail or social media platforms.

- Representatives from the surrounding world lecturing or working with the students in the school.

- The students working with assignments which require finding help from and/or report their results and actions to the surrounding world.

Using resources from the surrounding world in the purpose of providing an authentic and entrepreneurial learning environment can also be done by using information from the surrounding world, including published school material, magazines, news papers, information brochures and the Internet, as a complement to traditional school text books.

The surrounding world can be represented by companies, organizations, politicians, county-offices, institutes, other schools at different levels and the people in the community. CSS does not include experiences in nature, outdoor pedagogy or ordinary visits to science centers and museums, activities already presented elsewhere in science education literature.

\section{Authentic and entrepreneurial learning environments}

CSS makes use of resources in the surrounding world as a way to implement situations of more 'authentic learning' (e.g. Bencze \& Hodson, 1999; Braund \& Reiss, 2006; CERI, 1993; Hsu \& Roth, 2008; Lombardi, 2007; Rahm, Miller, Hartley \& Moore, 2003; Rule, 2006) and 'entrepreneurial learning' (Leffler 2006, Otterborg 2011). These approaches have evolved, partly as a response to students' declining interest in school science and technology in the developed world (Aikenhead, 2004; EU, 2004; Gilbert, 2006; Osborne, Simon \& Collins, 2003; Schreiner, 2006). Although used as concepts of 'learning' in literature, the present study focuses on the learning environment which is shaped by the teacher under the name of authentic and entrepreneurial 'learning'.

The study builds on education research concluding that increased student motivation, as well as lifelong and in-depth learning, can result from authentic and entrepreneurial learning situations. It focuses on the changed teacher demands and roles as teachers aim to use CSS as a way to help students reach curricular goals.

The previous curriculum for compulsory school in Sweden, Lpo94 (National Agency of Education, 1994/2006) required a teaching practice including CSS in science and technology education. This is further emphasized in the current curriculum, Lgr11 (National Agency of Education, 2011). 


\section{BACKGROUND}

The present study is part of a research project which focuses on the teacher's role in relation to the degree to which CSS gets integrated into science and technology teaching.

\section{Background to research focus}

Creating authentic and entrepreneurial learning environments, hence including CSS as an integrated part of teaching, is advocated for globally and from different perspectives by a variety of actors from the education research field (e.g. Aikenhead, 2004; Leffler, 2006) as well as from the working life and the political arena (e.g. EU, 2004; The Swedish Technology Delegation, 2009). Our rapidly changing society puts new demands on the skills and competences required for the students to learn in preparation for their future professional as well as social life. The new demands call for a shift in the view of what is meaningful for the students to learn, away from rote learning to a more holistic, contextualized, authentic and entrepreneurial learning, including humanistic, social and ethical values (e.g. Aikenhead, 2004; Doppelt, 2005; Leffler, 2006; Osborne et al. 2003).

It is not a recent observation by researchers within the education field that there is an undesired discrepancy between school education and the knowledge and skills required in daily life and work (e.g. Resnick, 1987) as well as between authentic, "real-life" activities and school activities (Brown, Collins \& Duguid, 1989; Lave, 1988).

Furthermore, there is a concern that the current decline, both over time and student age, in student interest in school science and technology is due partly to an education being performed in a manner and content which does not relate well with the students or their interests within these fields (Gilbert, 2006; Schreiner, 2006). Sharma and Anderson (2007) conclude that school science is shaped to fit into the school organization and the school's demands on assessment, rather than being shaped into a simplified version of more authentic science work including true inquiries, deliberations, and critical thinking. However, studies show an increased student interest and motivation when students are offered opportunities to work with societal issues of science and technology, hence use the surrounding world as a context and a resource in their learning process (e.g. Cerini, Murray, \& Reiss, 2003; Krogh \& Thomsen, 2005; Osborne \& Collins, 2001).

\section{The teacher's role in relation to CSS}

Among all actors interested in school education it can be argued that the single most influential actor, in regards to how the teaching is being executed, is the teacher (Aikenhead, 2004; Hattie, 2009; Leffler, 2006; Watters \& Ginns, 2000). The intentions of the curriculum, the teachers' formal steering document, have been shown to not always be realized even when teachers claim to have done so (Keys, 2005). Professional development is advised for curriculum changes to come true (Amaral \& Garrison, 2007). Thus, there is valid ground for distinguishing between the intended curriculum - the formal steering document - and the implemented curriculum - the way in which the education gets shaped by the teacher; the teaching practice.

Previous studies on teachers' role, situation, perceptions and attitudes towards an authentic and entrepreneurial teaching practice have not focused on collaborations from which authentic and entrepreneurial learning environments can emerge. Instead, the studies have looked into more general aspects of a variety of learning concepts related to CSS. Still, teachers' perceptions and attitudes have been identified to some degree, either from studies which have had a direct focus on the teacher's role, situation, attitude and perceptions in relation to a certain learning concept or from studies which have had a focus on the process of the project, the student learning and/or assessment issues.

Studies focusing on the teacher have revealed both barriers and favorable circumstances. E.g. Aikenhead (2004) reported that teachers asked about their perceived barriers for teaching with humanistic- 
cultural perspectives in a real-life context, experience fears of insufficient knowledge about integrated issues and the industrial context as well as not knowing more than the students. Other fears include not knowing how to control the class in a student-centered environment, not being able to follow the national text-book, not having control over the entire content as well as lack of support from school administration, from colleagues, from parents and from the community. Bungum (2003) adds struggles with the timetable to the list of teachers' perceived barriers. Teachers' concern regarding lack of control over the entire content knowledge is clearly expressed in studies on projects involving interdisciplinary (Tal \& Argaman, 2005) as well as inquiry-based learning (Crawford, 1999; Fishman, Marx, Best \& Tal, 2003).

In contexts of entrepreneurial learning, Leffler (2006) summarizes many of the above mentioned teacher barriers and concerns in describing the new relations between teacher and student, which in turn exposes the teacher to new challenges. Hence, it is the teacher who is exposed to new challenges, both in relation to the students and in relation to the teaching methods (author's translation, p 98). Favorable circumstances for successfully implementing humanistic-cultural science teaching, as perceived by teachers themselves (Aikenhead, 2004), include involvement in developing policies and materials as well as being part of supportive networks of teachers with the similar ambition. Furthermore, the respondents also commented that it is important that the individual teacher has a positive attitude towards change, is willing to deal with some degree of uncertainty in the classroom, gets directed professional development over a longer period of time, as well as time to reflect and discuss. The teachers also feel a need to have contacts with working scientists.

Studies focusing on the student learning out-come or the project process sometimes provide information also on teachers' perceptions. Teachers express concerns about how to assess learning objectives that are not subject-matter focused (Bencze \& Hodson, 1999; Doppelt, 2005). Views on meaningful knowledge can be a barrier to CSS if the assessment of the student learning is not aligned with the learning aims and methods of the project (Bonnette, 2006; Gustafsson \& Rystedt, 2009). Teachers' urge to keep "conformity and order" (Braund \& Reiss, 2006, p. 1384) can be a barrier. Teachers can experience an inhibiting sense of lack of control in a situation where they are learners themselves, together with their students, as they might be in a CSS context. This would put the teachers in a less authoritative position in relation to their students (Bencze \& Hodson, 1999). CSS is furthermore dependent on the teachers' personal attitude and willingness to include CSS. This, in turn, might include an issue of the degree of willingness to put in extra time outside of the school hours (Rahm et al., 2002). Teachers perceive the support from parents, students and the school principal as success factors for out-of-school projects (Bencze \& Hodson). The required support from the school management can include organizational and structural factors (Gustafsson \& Rystedt, 2009). Finally, the teachers need to feel that they share the ownership of the project together with the collaboration partner (Bencze \& Hodson).

\section{Purpose and research question}

The conclusion from previous studies relating to CSS is that requirements and barriers, as perceived and expressed by teachers, are basically the same whether the study focuses on teachers, students or the project itself. The only direction of concern, which shows up only in studies focusing on teachers, is the requirement of being part of a network between teachers with the similar ambitions to change their teaching to include more CSS.

The purpose of the present study is to identify teachers' perceived requirements for including CSS as an integrated part of teaching and to do so from the point of departure of the collaboration as well as with a focus on the teacher's role, identity and attitudes. The research question addressed is thus: What do teachers perceive as requirements for collaborating with the surrounding world as an integrated part of their teaching? 


\section{MetHOD}

\section{Selection of respondents}

Through a regional project in west-Sweden, in-service teachers in compulsory and upper secondary school all over the region were offered professional development courses on Entrepreneurial Learning. The initial empirical data were obtained from participants from four of these courses, as can be seen in Table 1.

- Group A had taken part in a one-day course on entrepreneurial learning and additionally, they took part in a five-day introduction course.

- Group B: The respondents took part in a continuation course, after having finished a five-day introduction course.

- Group C and Group D took part in a five-day introduction course.

The respondents are likely to constitute a positive selection since as many as $75 \%$ of the respondents had themselves registered for the course on entrepreneurial learning, which is expected to include CSS (Leffler, 2006). The same group of respondents clearly expressed a need and/or desire to either start introducing or further develop CSS as an integrated part of their teaching. The remaining $25 \%$ of the participants, who had been ordered by their respective school leader to take part in the course, contribute to a larger variation in the background of the respondents; hence possibly to a wider outcome space. The choice of respondents from these courses in Entrepreneurial Learning was, beside easy access, motivated by their insight into and interest in CSS; hence they could be presumed to have some thoughts and reflections on and/or previous experience from including CSS in their teaching.

Although the main focus of interest of the entire research project relates to CSS within science and technology teaching, all responses, regardless of subject taught by the respondent, were included to provide as many general categories of perceived requirements as possible.

\section{Data collection}

The data collection was done at the beginning of each respective course. Before responding, all participants were informed about the definition of CSS presented above. For groups A, B and C the participants were asked to answer three open-ended questions:

1. What do you perceive as requirements for including CSS into your teaching?

2. What do you perceive as barriers for including CSS into your teaching?

3. What do you perceive as barriers among your colleagues?

In group $\mathrm{A}$, the participants were given time during the course to fill in the questionnaire, resulting in a response rate of $100 \%$. In group $\mathrm{B}$ and $\mathrm{C}$, the questionnaires were handed out for later collection, resulting in the lower response rate seen in Table 1 . The participants in group D were asked to write

Table 1. Data on participants and respondents from courses on Entrepreneurial Learning

\begin{tabular}{|l|c|c|c|c|c|}
\hline Course code & A & B & C & D & Total \\
\hline Number of... & 10 & 31 & 24 & 32 & 97 \\
\hline participants & 10 & 10 & 15 & 32 & 67 \\
\hline respondents & $7 / 3$ & $6 / 4$ & $6 / 9$ & $20 / 12$ & $39 / 28$ \\
\hline female/male & & & & \\
\hline
\end{tabular}


their responses on 'post-it stickers' as an assignment included in their course, hence the response rate of $100 \%$. The respondents were also asked to specify who had signed them up for the course and what expectations they had. Finally, they also had to tell in what subject and at what level they teach.

All quotes have been translated by the authors. The respondents are mentioned with their code names, in which the initial letter stands for the name of the respondent group.

\section{Data analysis}

Specified requirements and barriers, as perceived and expressed by the respondents, were listed. The statements make clear concerns in different directions which have influence on the teaching practice. These different directions of concern, identified from the material without any predefined categories, make out the common factor within each main category. Barriers were turned into requirements, since they express a certain direction of concerns, e.g. the barrier "lack of time" was treated as a requirement for time. The statements within each main category were consecutively grouped into subcategories.

Furthermore, the number of respondents mentioning a certain direction of concern has been given more importance than the number of statements or subcategories included in each main category. This minimizes the error which lies in the subjective method of dividing the statements into smaller areas of concern as well as the error which is embedded in the respondents expressing basically the same requirement or concern in a variety of ways. Additionally, the purpose of the study is to clarify as many areas of concern - main categories- as possible, rather than providing quantitative information regarding different requirements.

With a view to the importance of the teacher as the single most influential actor on the implemented curriculum (2.2), the search for a pattern of a higher dimension is based on the influence which the individual teacher may have on the respective main category. Thus, the final categorization was based on the following criteria:

Category on which the teacher

- has no influence or a low degree of influence on an immediate or long-term basis

- has a high degree of influence on an immediate and long-term basis

- may have influence to a high degree over time

\section{RESULTS AND Discussion}

The requirements can be grouped into 13 main categories based on the area of concern which is addressed in each statement. The number of statements included in each main category varies. The main categories represented by a reasonably large number of statements can be grouped into subcategories. Six of the main categories - parents, students, curriculum and grading system, local curriculum, localities as well as union - have been grouped into other concerns in Table 2 since they can not be divided into subcategories. However, this is not a reflection of a valuation of the importance of the main categories included in other concerns. 
Table 2. Perceived requirements, presented as areas of concern, for including CSS as obtained from 67 respondents. Each respondent could list several perceived requirements. Each main category is represented by a number of statements (number in parenthesis), which have been divided into subcategories.

\begin{tabular}{|c|c|c|c|}
\hline $\begin{array}{l}\text { Main category } \\
\text { of perceived } \\
\text { requirement }\end{array}$ & $\begin{array}{l}\text { Number of } \\
\text { respon- } \\
\text { dents }\end{array}$ & $\begin{array}{l}\text { Number } \\
\text { of state- } \\
\text { ments }\end{array}$ & Subcategories \\
\hline $\begin{array}{l}\text { School mana- } \\
\text { gement }\end{array}$ & 39 & 61 & $\begin{array}{l}\text { Organization (28), which in turn includes } \\
\text { Schedule (15) } \\
\quad \text { Student group size (6) } \\
\text { General organisation (5) } \\
\text { Students with "special needs" (1) } \\
\text { General flexibility (1) } \\
\text { Support in development process for including CSS (16) } \\
\text { Decision making, clear demands/goals for including CSS } \\
\text { (11) } \\
\text { Participation and involvement in process for including } \\
\text { CSS (6) }\end{array}$ \\
\hline Time & 37 & 50 & $\begin{array}{l}\text { Time for planning: (18) } \\
\text { Together with colleagues (13) } \\
\text { On your own (5) } \\
\text { Time for carrying out the plan (4) } \\
\text { Time to reflect and adjust to new approaches (4) } \\
\text { Time to make contacts with the surrounding world (1) }\end{array}$ \\
\hline $\begin{array}{l}\text { Teacher's per- } \\
\text { sonal character } \\
\text { traits/disposi- } \\
\text { tion }\end{array}$ & 34 & 64 & $\begin{array}{l}\text { Courage (30) } \\
\text { to try something new (19) } \\
\text { to break norms and traditions (4) } \\
\text { to let go of control (4) } \\
\text { to 'fail' (3). } \\
\text { Engagement (8), curiosity and interest (4) } \\
\text { Will to change things (7) } \\
\text { Ability to take initiative/to recognize possibilities (4), } \\
\text { Self confidence and Pro-activeness (3) } \\
\text { Creativity and Imagination (5) } \\
\text { Empathy (1) } \\
\text { Being a positive role model (1) }\end{array}$ \\
\hline Colleagues & 25 & 38 & $\begin{array}{l}\text { Joint participation and decision making (12) } \\
\text { Coherent views on teaching and education (7) } \\
\text { Positive attitude in general and towards changes speci- } \\
\text { fically (9) } \\
\text { Ability to listen to and understand each other's different } \\
\text { situations (6) } \\
\text { Support and generosity (4) }\end{array}$ \\
\hline $\begin{array}{l}\text { Surrounding } \\
\text { world }\end{array}$ & 22 & 28 & $\begin{array}{l}\text { Positive attitude (8) } \\
\text { Win-win collaborations (8) } \\
\text { In close vicinity (6) } \\
\text { Network of contacts (5) } \\
\text { Simplicity (1) }\end{array}$ \\
\hline
\end{tabular}


Table 2 continued

\begin{tabular}{|l|l|l|l|}
\hline $\begin{array}{l}\text { Main category } \\
\text { of perceived } \\
\text { requirement }\end{array}$ & $\begin{array}{l}\text { Number of } \\
\text { respon- } \\
\text { dents }\end{array}$ & $\begin{array}{l}\text { Number } \\
\text { of state- } \\
\text { ments }\end{array}$ & Subcategories \\
\hline Economy & 18 & 21 & $\begin{array}{l}\text { In general (11) } \\
\text { Transportation (10) }\end{array}$ \\
\hline $\begin{array}{l}\text { Professional } \\
\text { development }\end{array}$ & 17 & 19 & $\begin{array}{l}\text { For inspiration (8) } \\
\text { For a change in attitude/approach (7) towards the stu- } \\
\text { dents' resources, the schools' overall commission as well } \\
\text { as towards interdisciplinary teaching and to regard CSS } \\
\text { as a 'pedagogical method'. } \\
\text { For development work in general (2) }\end{array}$ \\
\hline Other concerns & 35 & 39 & \\
\hline
\end{tabular}

Table 3 presents the result of the analysis of the degree of influence which the individual teacher may have on each main category; the degree of influence can vary for the same requirement.

Table 3. The individual teacher's degree of influence on each respective main category of perceived requirements for including CSS.

\begin{tabular}{|l|c|l|l|}
\hline $\begin{array}{l}\text { Main category of perceived } \\
\text { requirement - } \\
\text { area of concern }\end{array}$ & $\begin{array}{l}\text { Low degree of } \\
\text { influence }\end{array}$ & $\begin{array}{l}\text { High degree of } \\
\text { influence }\end{array}$ & $\begin{array}{l}\text { Influence over } \\
\text { time }\end{array}$ \\
\hline School management & $\mathrm{x}$ & & \\
\hline Colleagues & $\mathrm{x}$ & & \\
\hline Surrounding world & $\mathrm{x}$ & & \\
\hline Economy & $\mathrm{x}$ & & \\
\hline Union & $\mathrm{x}$ & & \\
\hline Localities & & $\mathrm{x}$ & \\
\hline $\begin{array}{l}\text { Curriculum and grading } \\
\text { system }\end{array}$ & $\mathrm{x}$ & $\mathrm{x}$ & \\
\hline $\begin{array}{l}\text { Teacher's personal character } \\
\text { traits and disposition }\end{array}$ & $\mathrm{x}$ & $\mathrm{x}$ & \\
\hline Professional development & & & \\
\hline Goals of local curriculum & & & \\
\hline Time & & & \\
\hline Students & & & \\
\hline Parents & & & \\
\hline
\end{tabular}




\section{School management}

School management is perceived to be the most important area of concern. This is in coherence with previous studies (Aikenhead, 2004; Bencze \& Hodson, 1999). Different areas of concern, for which the school management holds or is perceived to hold responsibility, are addressed within this main category. The statements include indirect as well as direct expectations. Indirectly, the school management is expected to support CSS on an organizational and structural level, where a flexible school schedule is the most frequently mentioned requirement:

School without time-planned lessons. Possibility. Nothing is impossible. Flexibility. (D12)

Many different groupings in a silly schedule where physical education and crafts take up a lot of space. (B12)

CSS might involve interdisciplinary assignments as well as out-of-school contacts at different times than those offered on the schedule for a specific subject; hence it is easy to understand the teachers' requirement of longer, uninterrupted lessons, also in line with Bungum's (2003) study. Apart from issues around the school schedule, student group size as well as general organizational factors and flexibility are brought up as concerns. Gustafsson and Rystedt (2009) find requirements on organization and structure perfectly understandable. They conclude from a study on an authentic learning project that 'the education was reshaped and adjusted to the institutional environment' (p.125, author's translation) instead of the other way around.

Direct support from the school management includes decision making and clearly specified school goals for CSS as well as a demand that this actually happens. The teachers need re-assurance that CSS is a prioritized goal for school development; the statements reveal a frustration over the impression of getting new tasks added without any previous ones being reduced:

School management must use the power of decision to turn the old school upside down. Support is needed. Motor for change with the power to enforce it. Provide support when the way of working is questioned. (D12)

Is required: Concrete and realistic description of teacher's work assignment. If something is to be added then something else must be taken away! (D19)

Additionally, the school management needs to take active part in the implementation of CSS:

One barrier is a head master who is not actively taking part in the process. (D29)

We conclude that school management is one of the categories on which the individual teacher experiences a low degree of influence.

\section{Time}

Time is a category on which the individual teacher can have a high as well as a low degree of influence. It is a multi-dimensional category in the sense that time is required as minutes and hours but also, and possibly more importantly, as time to adjust to new approaches and attitudes to teaching. The latter aspect of time has not been addressed in the previous studies.

Time in itself is, in some aspects, strongly intertwined with the school management. There is a need for scheduled time for pedagogic discussions around CSS as well as shared reflection and lesson planning. This is an organizational/structural issue for which the school management is held responsible. Since including CSS would be a new way of teaching for many of the respondents and they would need to make new contacts with the surrounding world, it is understandable that there is a requirement of getting extra time initially in the process of renewing lesson plans. This is required not only on an individual basis but also on a teacher team basis:

It [including CSS in teaching] initially means some extra work time. (C19)

Time to shape this way of teaching. (B15) 
The sense of having to work extra hours initially when starting to work with CSS is addressed in previous studies as well (Rahm et al., 2003) just like the desire to jointly develop materials (Aikenhead, 2004) and having time to network with other teachers with the same ambition (Bencze \& Hodson, 1999). The scheduled time for pedagogic discussion and joint planning can additionally be a way for the school management to signal a priority to CSS goals:

Time within the work hours. (C27)

Time for planning is eaten by other tasks. (D29)

Although the statements in this category again indicate frustration over not having enough time, some also illustrate awareness about the individual teacher's possibility to re-organize some of the working hours according to the goals set by the school management:

Time must be available, and you, yourself, have to take time of your own. (Do2)

The Swedish context in this study makes it relevant to address the Swedish teachers' freedom of being able to do approximately $20 \%$ of the weekly working hours, outside of instruction and the conference time, at any place and time. The time-related statements indicate the respondents' awareness about the possibility to organize this time according to individual professional priorities.

Time is additionally expressed to be needed to implement the new lesson plans and ways of teaching, which in turn need to be evaluated before any results can be measured and discussed. Time further needs to be allowed for revision since the teachers do not expect that the newly introduced CSS will always turn out as planned or expected. This is a requirement of time in a long-term perspective:

Allow time for change. Planning, application, evaluation and revision. (D16)

The statements illustrate teachers' awareness of the fact that introducing a different way of or approach to teaching requires time to individually reflect on as well as adapt and mentally adjust to the changes, if to be done in a committed manner. Time is thereby needed on a different level than the ones mentioned above; this is time for a mental process, which can and does take place independently of where the teacher is in space or time.

It takes time to adjust to something new. Make a sincere effort. Take something away to make time for the important things. (D16)

Finally, there are statements which express the teachers' awareness of the students and parents also needing time to adjust to the shift in the view on meaningful knowledge away from a focus on subject matter towards a focus on the learning process and different competencies:

The parents need to be informed about the shift in the view on what is useful knowledge to attain in compulsory school, away from a focus on subject matter towards a focus on the process of learning. (D20)

The perception of having to work extra hours initially when starting to work with CSS, mentioned above, is additionally dependent on the willingness to do so. This, in turn, has to do with the teacher's personal character traits and disposition, another main category. This would be true also for the time needed to adjust to new attitudes, since the individual teacher has to be willing to change attitudes. Changes, in turn, might depend on professional development, in turn dependent on the school management. These are yet other examples of interdependency between the main categories.

\section{Teachers' personal character traits and disposition}

The recognition of the important role of the individual teacher to shape the teaching in the classroom is reflected in the responses, which also indicate a belief that an individual's attitudes, character traits and disposition can change due to professional development as well as personal and professional experiences, hence the individual teacher has a high degree of influence on the main category teacher's 
personal character traits and disposition. Personal courage is by far perceived as the single most significant factor within this category. It is perceived to take courage to be able to let go of control, which is in coherence with previous studies where teachers express fears of what might happen when including CSS (Aikenhead, 2004; Bencze \& Hodson, 1999; Braund \& Reiss, 2006; Crawford, 1999; Fishman et al., 2003; Tal \& Argaman, 2005).

Dare to let go of the control. How you do in the class room. It might not turn out the way one expects. Have fun at work! (D15)

Further, the requirement of courage to try something new, to break norms and traditions and to be prepared to fail in doing so confirms Leffler's (2006) argument that teachers have to possess entrepreneurial skills themselves to be able to allow and promote entrepreneurial student learning including CSS.

Traditions can be a barrier. They sit in the walls. Habits! Territorial thinking. Is it possible to break the boundaries? Dare to change habits! Create new traditions! Dare to risk failure. (D7)

Further valued aspects of personal character traits include curiosity and interest, imagination and creativity as well as the ability to recognize possibilities. The latter might have to do with a will to change things. The ability to take initiative and being pro-active might be related to the teacher's self confidence and engagement. These are, again, examples of a teacher's entrepreneurial skills perceived as required. Finally, understanding of other people's situation and being a positive role model are mentioned as properties that are perceived as requirements for CSS:

That I as a teacher am aware of the possibilities available. (D19)

Imagination and creativity. See possibilities to open new doors. (Do8)

In summary, the variety and abundance of statements within this main category indicate that the respondent teachers value personal qualities in relation to professional performance and development.

\section{Colleagues}

Many responses emphasize the role of colleagues. The statements reveal teachers' fear of working and taking decisions on their own when introducing CSS, confirming previous studies (Aikenhead, 2004). Coherent views among the colleagues are required to a certain degree; when not fully in agreement, the ability to listen to and understand each other's different perspectives and working situations is of more importance. Additionally, the requirements on the personal character traits and disposition, which teachers hold on themselves; they also hold on their colleagues.

A functioning teacher team with a lot of give and take. (C25).

A good team-work climate. Everyone in the group must feel secure. Creativity thrives. (Do3).

Although the phrases "teacher's team" and "colleagues" refer to the same group of people, the term "teachers' team" is more frequently mentioned in relation to requirement, whereas "colleagues" is more frequent in relation to barriers.

Understanding and will in the teachers' team. (B17)

Conservative colleagues. Fear of change is huge. Function as a break to too much enthusiasm. (D25)

Since projects involving collaboration with the surrounding world often are of an interdisciplinary character this category is often mentioned in connection with school management as well as time in the context of facilitating teachers' internal collaboration. In the short term, teachers have a relatively low degree of influence on their colleagues. 


\section{Surrounding world}

The respondents recognize the importance of the collaboration to be beneficial to both parties; hence the partner has to be able to see both short- and long-term benefits. The long-term benefits can include an increased student interest in science and technology to the level that the students choose this career path (e.g. Aikenhead, 2004; NRC, 2000). This, in turn, is additionally the argument for CSS from the political arena (EU, 2004) for the purpose of securing the re-growth in the fields of science and technology.

A positive attitude towards CSS in the surrounding world is also expressed as a requirement which has an impact on the possibility to make contacts with representatives from the surrounding world and build up a network.

To find good and interested contacts who make us work toward the learning goals. A long-term engagement - not just "happenings" (B11)

[The collaboration] must not just be a burden for the company, but an asset. (Ao3)

Barriers expressed by the respondents illustrate that there are teachers who have had negative experiences in previous contacts; poor reception by the contact and lack of interest, a higher tempo in working life and uncertainty of the expectations of companies, including their expectations on school classes.

Building confidence takes time. There is a considerable risk that the work is wasted. The companies think about their own benefit. If an employee has a child in school, they will be more interested. (C31)

Although teachers may have a choice, they can exert only a limited influence on the people with whom they are going to collaborate in the surrounding world.

\section{Economy}

Economy has not been mentioned in the previous studies and might be a particular concern for Sweden, since all education is required by law to be free of charge for all students. This is a very important category for the political and industrial CSS advocators (e.g. EU, 2004) to consider. The issues on economy mainly concern ways to pay for travel and activities. Almost all replies in this category were brought up as a barrier, often in a one-worded manner; "economy" or "money". The more extended answers mentioned economy or money in relation to transportation:

Difficulty to reach places far away - economy. (A17)

Economy is a main category on which the individual teacher has a very low degree of influence.

\section{Professional development}

The expressed need for professional development is clearly on different levels, from a desire to get inspiration from concrete and successful examples of how to work with CSS to a more in-depth and reflective process of changing ones attitude/approach to different aspects of education and teaching. Required reflections include questions regarding CSS as a pedagogical method, as well as questions regarding learning objectives, meaningful knowledge and re-designing assessment methods to better reflect the changed view on knowledge.

Concrete tips!! So that you don't have to think about how to do it. How to get it into your practice. (D12)

Lack of knowledge - belief that it is bigger and more cumbersome/difficult/complicated than it really is (Bo3)

This type of demands were found, for example, also by Aikenhead (2004), Bencze and Hodson (1999), Bonnette (2006), Braund and Reiss (2006), Doppelt (2005) as well as Gustafsson and Rystedt 
(2009). The present study further reveals that many teachers perceive professional development for the whole teacher's team as a requirement.

Knowledge and inspiration. Supervision. All teachers/pedagogues should take part in courses to get inspired and interested. Find new "tracks". Education. (D14)

Professional development is a category, like time, on which the individual teacher has a strong as well as a low degree of influence. This is clearly reflected in the statements; the individual teacher needs to be willing to take part in professional development -which makes this category intertwined with personal character traits and disposition- but is also dependent on support from the school management to be able to take part within working hours, which in turn relates to time.

\section{Other concerns}

The concerns described above where brought up respectively by at least a quarter of the respondents. The remaining concerns were mentioned by at most $1 / 8$ of the respondents. Four respondents do not perceive any particular requirements for including CSS.

Parental support. This support is required on different levels. The practical support involves transportation to and from activities outside of the school building, thus confirming previous studies (Bencze \& Hodson, 1999). The other level of parent support required concerns pedagogical aspects; the respondents are aware that the parents' attitude towards and perception of education and teaching, based on their own school experiences, could be a barrier on the basis of CSS being a "new" way of teaching. The respondents do not expect the parents to be used to CSS nor to immediately recognize the learning value of it:

Parents views of school [barrier]. Needs a lot of information. Educate the parents. What about goals and grades? (D22)

However, some respondents mean that the parental support is more of a desire than a requirement. Yet other statements point out that the parents' knowledge and experience can be used as one way of including CSS.

The individual teacher might have some influence over time on the support from the parents, through informative meetings and reflective discussions on pedagogic methods and objectives. Similarly, the individual teacher could, over time, have some influence on the support from the students. A few of the responses reveal a worry about the students' behavior outside the school:

A few pupils' bad behavior. (Bo5).

The demands on safety, and the responsibility for transport, as well as the need for permission from parents to publish pictures of the pupils. You do not always feel secure with all pupils outside. (Ao3)

In this sense, support from the students is intertwined with the teacher's personal character traits and disposition, in which courage and different fears are included (3.7). Naturally, a positive attitude among the students would lower the threshold for the teacher to take the students to visits outside school:

The pupils need not be enthusiastic, but need to have a positive attitude to what is offered. (D13).

The national curriculum and grading system is strongly linked with the local curriculum, which is yet another area of concern which has not previously been addressed. Goals and criteria for grades for the students are specified in the national curriculum (National Agency of Education, 1994/2006). However, in Sweden the curriculum is further adapted by the local schools into a local curriculum. Since the school's prioritized goals, specified by the school management, should be taken into account in the process of formulating the local curriculum, this is yet another example of the intertwined 
character of the main categories. Some statements highlight the importance of CSS being included in such a manner that it actually helps the students reach the goals of the local curriculum. There is a concern that the learning from CSS might not be valuable enough:

Need to find good, interested contacts that make us work towards the curricular goals. A longterm involvement. It must not just be "happenings". (B11)

We have the learning goals! We must not forget that. (B19)

The individual teacher does not have any influence on the national curriculum and the grading system, however may have a high degree of influence over the local curriculum, depending on the coherence among the teachers on the school or in the teachers' team.

The localities make out a main category on which the individual teacher has only a small, if any, degree of influence and it is not been brought up as a direction of concern in previous studies. Some respondents state that the traditional classroom is not necessarily adapted for today's teaching methods (Do1) and that the rooms available to some extent direct the school activities (D11).

The union, which is mentioned by four respondents, has not been brought up in previous studies. In the present study it was brought up only as a barrier, not as a requirement. The individual teacher has a low degree of influence on the union, since the purpose of the union is to primarily represent the teachers' community.

The Union. The biggest barrier. Plays too big of a role. (D14)

Possibly the concern about the union has to do with the dilemma which a teacher pointed to in a previous study; namely the willingness to put in extra time outside of school hours for the project to succeed (Rahm et al., 2003). In Sweden there is, and has been for several years, a discussion on the increased intensity of the profession and the new demands which keep on being added to the teachers' working assignments. Several replies in this study illustrate teachers' frustration over the feeling of always lacking time for the work which they need and want to do in a qualitative manner, as described under school management and time.

Furthermore, and put forward in the union context, there is a concern about the added responsibilities which arise as soon as you take the students out of the school building, which has additionally been mentioned in relation to students.

The demands on security and responsibility for transportation. And permissions to publish pictures of the students. The students' sense of security. The teacher does not feel secure enough with all the students out of the school building. (AO3)

\section{CONCLUSION}

This study shows teachers' perceived requirements for including CSS in their teaching. Many requirements have been found also in earlier studies. However, the requirements concerning economy, localities, the local curriculum and teachers' unions do not seem to have been mentioned before. Additionally, the aspect of time as in time to reflect, process and re-adjust to a new way of both shaping the teaching practice and valuing student knowledge and skills is a concern not discussed in earlier work. Furthermore, the open responses in the present work add more detailed information and dimensions of the teachers' perceptions and attitudes regarding the previously identified requirements. In view of the teacher's influence on the implemented curriculum (Amaral \& Garrison, 2007; Keys, 2005) it is important to recognize the influence of the individual teacher also on the use of CSS.

This study makes clear that the identified requirements, although distinguished in the analysis of the responses, are more or less intertwined in one way or another. Using a cobweb metaphor, the requi- 
rements form the nodes and the relations between the requirements form the threads between the nodes in the cobweb. Within the cobweb all links need to be taken into consideration, even though the nodes are important to identify and be aware of. From this mutual dependency follows that the degree, to which the individual teacher has influence over each node, can not be expressed in a definite manner, as exemplified several times above.

The statements included in teacher's personal character traits and disposition exhibit teacher awareness about the role the individual teacher has on the implemented curriculum as well as the role the teacher plays in school development. Starting to include CSS in teaching or increasing the degree to which it is included can be considered to be school development. Teachers who want to change their own teaching practice face many dilemmas (Anderson, 2007) which, in turn, make out paradoxes (Berger et al., 2005); the teachers want external support to realize a development project while they on the same time rely heavily on their own knowledge and experience. Research further reveals that collaboration among colleagues is a powerful factor in an initiative to change teaching approaches (Anderson, 2007, Bransford et al., 1999). Despite the influence the teachers have over the implemented curriculum, research also shows that teachers' professional development has to be nourished from a systemic and multifaceted support. A majority of the issues and dilemmas found in these studies on different aspects of professional development towards a certain change in teaching have been addressed, confirmed and developed by the respondent statements in this study. The rich and freely expressed statements have further added new information for a better understanding of how to support teachers to start including CSS or to increase the degree to which CSS gets included and integrated into the teaching practice.

\section{REFERENCES}

Amaral, O.M. \& Garrison, L (2007). Missing the Forest for the Trees. Journal of Science Education and Technology, 16(2), 155-169.

Aikenhead, G.S. (2004). The humanistic and Cultural Aspects of Science and Technology Education. Paper presented at the 11th International Organisation for Science and Technology Education (IOSTE) Symposium, July 25-30, in Lublin, Poland.

Anderson, R.D. (2007). Inquiry as an Organizing Theme for Science Curricula. In S.K. Abell and N. G. Lederman (Eds.), Handbook of Research in Science Education (pp. 807-830). New Jersey: Lawrence Erlbaum Ass.

Bencze, J.L.\& Hodson, D. (1999). Changing Practice by Changing Practice: Toward More Authentic Science and Science Curriculum Development. Journal of Research in Science Teaching, 36(5), 521-539.

Berger, J.G., Boles, K.C. \& Troen, V.(2005). Teacher research and school change: paradoxes, problems, and possibilities. Teaching and Teacher Education, (21), 93-105.

Bonnette, R. (2006). Out of the classroom and into the community: Service learning reinforces classroom instruction. The Technology Teacher, International Technology Teacher Association.

Bransford, J.D., Brown, A.L. \& Cooking, R. (1999). How People Learn: Brain, mind, experience and school. Washington, DC: National Academy Press.

Braund M.\& Reiss, M. (2006). Towards a More Authentic Science Curriculum: The Contribution of out-of-school Learning. International Journal of Science Education, 28(12), 1373-1388.

Brown, J.S., Collins, A. \& Duguid, P. (1989). Situated Cognition and the Culture of Learning, Educational Researcher, 18, 32-42.

Bungum, B. (2003). Perceptions of Technology Education. A cross-case study of teachers realizing technology as a new subject of teaching. PhD dissertation, Norwegian University of Science and Technology, Trondheim.

CERI. (1993). Active and Authentic Pedagogy - Description of a CERI Study on New Ways of Teaching and Learning. Paris: OECD. 
Cerini, B., Murray, I. \& Reiss, M.J. (2003). Student review of the science curriculum. Major findings. London: Planet Science; Institute of Education, University of London; Science Museum.

Crawford, B. (1999). Is It Realistic to Expect a Pre-service Teacher to Create an Inquiry-based Classroom? Journal of Science Teacher Education, 10(3), 175-194.

Doppelt, Y. (2005). Assessment of Project-Based Learning in a Mechatronics Context. Journal of Technology Education, 16, 7-24.

EU, 2004. Europe needs scientists! Brussels: European Commission, Directorate-General for Research, High Level Group on Human Resources for Science and Technology in Europe.

Fishman, B., Marx, R.W., Best, S. \& Tal, R.T. (2003). A design approach to professional development: Linking teacher and student learning in systemic reform. Teaching and Teacher Education, 19, $643-658$.

Gilbert, J. (2006). On the Nature of "Context" in Chemical Education. International Journal of Science Education, 28(9), 957-976.

Gustafsson, J. \& Rystedt, H. (2009). Att lära i och för arbetslivet - Myter och utmaningar. Pedagogisk Forskning i Sverige, 14(2), 110-131. Göteborgs Universitet, Institutionen för pedagogik och didaktik.

Hattie, J. (2009). Visible learning - A synthesis of over 800 meta-analyses relating to achievement. London, Routledge.

Hsu, P-L. \& Roth, W-M. (2008). An Analysis of Teacher Discourse that Introduces Real Science Activities to High School Students. Research in Science Education, doi: 10.1007/s11165-008-9094-9.

Keys, P.M. (2005). Are teachers walking the walk or just talking the talk in science education? Teachers and Teaching: theory and practice, 11(5), 499-516.

Krogh, L.B. \& Thomsen, P. V. (2005). Studying students' attitudes towards science from a cultural perspective but with a quantitative methodology: border crossing into physics classroom. International Journal of Science Education, 27(3), 281-302.

Lave, J. (1988). Cognition in practice. Boston, MA: Cambridge.

Leffler, E. (2006). Företagsamma elever - Diskurser kring entreprenörskap och företagsamhet $i$ skolan. PhD dissertation, University of Umeå, Sweden.

Lombardi, M.M. (2007). Authentic Learning for the 21st Century: An Overview. Educase Learning Initiative Paper (1).

McCombs, B. L., (1996). Alternative perspectives for motivation. In L. Baker, P. Afflerback.\& D. Reinking, (Eds.), Developing Engaged Readers in School and Home Communities. Mahwah, NJ: Erlbaum.

National Agency for Education. (2006). Curriculum for the compulsory school system, the preschool class and the leisure-time centre, Lpo 94. Ödeshög: AB Danagårds Grafiska. (Original work published in 1994.)

National Agency for Education. (2011). Curriculum for the compulsory school system, the pre-school class and the leisure-time centre, Lgr11. Västerås, Edita.

National Research Council. (2000). How People Learn - Brain, Mind, Experience and School. Washington DC, National Academy Press.

Osborne, J. \& Collins, S. (2001). Pupils' views of the role and value of the science curriculum. International Journal of Science Education, 23(5), 441-467.

Osborne, J. Simon, S. \& Collins, S. (2003). Attitudes towards science: a review of the literature and its implications. International Journal of Science Education, 25(9), 1049-1079.

Otterborg, A. (2011). Entrepreneurial learning. Upper secondary school students' different perceptions of entrepreneurial learning. PhD Dissertation, School of Education and Communication, Jönköping University, Sweden.

Rahm, J., Miller H., Hartley, L. \& Moore, J. (2003). The value of an Emergent Notion of Authenticity: Examples from Two Student/Teacher - Scientist Partnership Programs. Journal of Research in Science Teaching, 40(8), 737-756.

Resnick, L.B. (1987). Learning in School and Out. Presidential Address at AREA, April, in Washington DC, USA. 
Rule, A.C. (2006). Editorial: The Components of Authentic Learning. Journal of Authentic Learning, 3(1), 1-10.

Sharma, A.\& Anderson, C. W. (2009). Recontextualization of Science from Lab to School: Implications for Science Literacy. Science and Education. 18(9), 1253-1275.

The Swedish Technology Delegation. (2009). Informationsbroschyr. Statens Offentliga Utredningar. SOU 2010:28.

Schreiner, C. (2006). Exploring a ROSE-garden: Norwegian youth's orientations towards scienceseen as signs of late modern identities. PhD dissertation, University of Oslo, Norway.

Tal R. \& Argaman, S. (2005). Characteristics and Difficulties of Teachers Who Mentor Environmental Inquiry Projects. Research in Science Education, 35, 363-394.

Watters, J.J. \& Ginns, I. S. (2000). Developing Motivation to Teach Elementary Science: Effect of Collaborative and Authentic Learning Practices in Preservice Education. Journal of Science Teacher Education, 11(4), 301-321. 